\title{
Medium-term forecast of European economic sustainable growth using Markov chains*
}

\author{
Alina-Petronela Haller ${ }^{1}$, Ovidiu Gherasim ${ }^{2}$, Mariana Bălan ${ }^{3}$, \\ Carmen Uzlău 4
}

\begin{abstract}
Economic growth is a frequently analyzed aspect, both from theoretical and empirical standpoint, under the impact of the influence factors, while the issue of economic growth was studied by applying different methods and obtaining different results. In the case of EU28, the problem of economic convergence has to take into consideration the fact that the Member States are heterogeneous in terms of development and rate of growth. In the present paper, by using Markov chains we have made, a forecast of the GDP per capita evolution for the economies of the EU28 members, starting from the known time horizon - 1997-2016 as to approach a forecast horizon - 2017-2028. The results obtained show that the convergence process will be a slow one in the case of some Member States, especially in the Central and Eastern Europe. The future economic dynamics will intensify growth
\end{abstract}

* Received: 10-05-2020; accepted: 01-12-2020

1 PhD Senior Researcher, Romanian Academy Branch of Iași- "Gh. Zane” Institute for Economic and Social Research, Codrescu Str, No. 2, 700481, Iasi, Romania. Scientific affiliation: economic growth, economic development, inequalities, international tourism, international economics, macroeconomics.E-mail: alina_haller@yahoo.com. Personal webpage: https://sites.google. com/view/alinahaller/home. ORCID ID: https://orcid.org/0000-0002-2069-9889.

2 PhD Senior Researcher, Romanian Academy Branch of Iași - "Gh. Zane” Institute for Economic and Social Research, Codrescu Str, No. 2, 700481, Iasi, Romania. Scientific affiliation: fuzzy systems, applied mathematics, informatics systems.E-mail: ogacadr@yahoo.com.

3 University Professor and PhD Senior Researcher, Institute for Economic Forecasting NIER, Romanian Academy, Casa Academiei, Calea 13 Septembrie No.13, 050711, Bucharest, Romania. Scientific affiliation: economic forecasting, econometrics and modelling, economic statistics, macroeconomics, population and labour force mobility, labour market, demoeconomy, developing public policies for youth employment, education market, technological progress vs. education and human resources training.E-mail:dr.mariana.balan@gmail.com.

${ }^{4}$ PhD Senior Researcher, Institute for Economic Forecasting - NIER, Romanian Academy, Casa Academiei, Calea 13 Septembrie No.13, 050711, Bucharest, Romania. Scientific affiliation: education market, social protection, fiscal policies, macroeconomics, economic development, economic statistics.E-mail: carmen.uzlau1812@gmail.com. 
divergences, especially in the case of the European periphery, which will suffer minor modifications; the states with the most significant gaps will remain Bulgaria and Romania.

Key words: economic growth, Markov chains, medium-term forecast, convergence, EU28

JEL classification: F43, N10, O11, O47, O52, R11

\section{Introduction}

Growth and development that are to result in ensuring people's well-being and environmental protectionist processes to which converge all the actions undertaken by economy and society. It is necessary to point out here that we do not put a sign of equation between growth and development. Both processes are intensely theorized but there is still room for estimations and forecasts, given the importance of growth, whose finality is development. We are preoccupied with the long-run evolution of the European society and economy Therefore, in the present analysis by applying the method of Markov chains, our aim is to forecast the future economic growth of EU28 Member States. Economic literature extensively analyses the causality of growth, without clearly establishing a set of factors that would be valid for all countries, under all circumstances. Each economic entity answers in a different way to certain stimuli, this is a fact that reality and complex researches have demonstrated.

Sustainability has been applied to a wide range of situations, the sustainability criteria depending a lot on the context, based on a common characteristic, namely that it is a concept that manifests itself in the long term (D'Ergole and Salvini, 2003). Sustainable growth is the process that ensures the over-size of wealth, over time, without periods of strong decline caused by the exaggerated use of limited natural resources or environmental degradation in production and consumption processes. Each country faces with different challenges in its path to sustainable development and seeks, in this regard, to lay a sustainable foundation so that in the future prosperity will grow concurrently with the sustainable management of resources (UNDP, 2017). Sustainable growth is subject to risks such as climate changes that require good resource management and adaptive capacity, hunger and poverty that are eradicated, inequalities of income that are required to be corrected, massive urbanization, provision of increasing amounts of energy, crises financials that require prevention and management. Sustainability is directly related to the environment, and the relationship between growth and the environment is not well understood, so as it will be understood in the future, the solution for sustainable growth will be the implementation of zero emission technologies.

Our purpose is not to analyse the causes of growth for the EU28 members, but only the future evolution of this quantitative process for each state, mentioning 
the differences in the form of growth gaps, given that within the EU28 framework, economic standardization is desirable. The less developed Member States who joined the Union with the latest enlargements wish for the economic and social differences to be reduced, so that their populations could enjoy a standard of life similar to that of the population in the developed member countries.

The process of economic growth is defined, in simple terms, as an increase of the real GDP, real GDP per capita, real GDP growth rate and real GDP per capita growth rate (Sekreter, 2015), while its importance comes from the fact that it underlies development, without being its only condition. Although no unanimously accepted perspective has appeared by now, economic growth reflects aspects of quantitative nature, unlike development, which is essentially qualitative. Growth allows for increase of an economy's size, of the macroeconomic indicators, particularly of the GDP per capita, in an ascendant but not necessarily linear way, with positive longterm effects, subjected to constraints such as the excessive growth of the population, limited resources, inappropriate infrastructure, inefficient utilization of resources, excessive governmental interference, institutional and cultural models that might slow down growth. The present paper focuses on growth and not on development because growth underlies development and there is no equivalence between the two processes, as a country has the possibility to grow without developing, while the reverse is not true.

The economic convergence of developing and the less developed countries is vital in order to reduce the gap compared to the developed economies, an objective that ensures a higher standard of life and status for their population. As far as the EU28 is concerned, it aimed at becoming a strong construction, but for the time being it is only a vulnerable, yet to be the finalized one (Stiglitz et al., 2014). EU28 progresses at different speeds in spite of the desiderata of making it work as a whole. One of the proposed objectives is the convergence of the less developed states and the reduction of the gap compared to the regional average by improving the conditions of growth and employment (Fontaine, 2010). The difficulty comes from the differences in terms of growth and development between the members, as well as from the way in which some of them manage to reduce gaps with the developed countries of EU28. If the best results were recorded by the north states, Finland, Sweden, and Denmark, at the other end of the scale we can find Greece, Romania and Bulgaria (Ardielli, 2016).

The factors of economic growth are different from state to state, some of them being sustainable, supporting the process in the long run, others less sustainable, as they support the process for shorter terms. The positive rates of economic growth, regardless of the determinant factors, theoretically reduce the development gaps between the European countries. Landon-Lane and Robertson (2009) reached the conclusion that, except for the golden period following World War II, one can observe a reduced $\beta$-convergence or not find it at all; the period after WWII 
represents an anomaly of the growth process in the long run. Between the European regions, gaps persist between GDP per capita values and incomes, in spite of an increasingly higher degree of openness (Le Gallo, 2004). Convergence studies have their origin in the theory of economic growth being initially introduced by Solow (1956) later developed by Barro (1991) and Barro and Sala-i-Martin (1992) and then to be a widely accessed method to study the macroeconomic aspects of growth. Baumol (1986) developed the $\beta$-convergence equation to show its type (conditioned when the $\beta$ value is positive and unconditioned when the $\beta$ value is negative) and its speed.

Smętkowski and Wójcik (2010) studied the tendencies and factors of growth in sub-regions of Central and Eastern Europe for the period 1998-2006, reaching the conclusion that the integration of central and eastern European states helped to reduce the national and regional disparities in terms of income per capita and GDP per capita. Iancu (2009) gives special attention to Romania's case, which he describes as a peripheral European country from the point of view of the GDP per capita level, the indicator value being much under the EU average. Analyzing Romania's process of convergence to EU15 and the leader states Germany and France for the periods 1980-2003 and 1990-2004, Iancu reaches the conclusion that in Romania's case convergence is a simple illusion, while gaps, instead of decreasing, intensified.

In the present paper, we validate Iancu's hypothesis, starting from the analysis of GDP per capita as an indicator of growth for each European member. The forecast made by means of Markov chains shows an intensification of the growth gaps between the center and the periphery of EU28 by 2028. The Markov chains represent a successfully used methodology in order to demonstrate different hypotheses in varied fields of research. The novelty brought forth by our paper is the forecast of economic growth, measured in GDP per capita, for the next three decades, a forecast which confirms the intensification of growth gaps between the periphery and the developed European states, with two exceptions, starting from the economic reality of the last two decades, and noticing Romania's considerably lower performance compared to the rest of the peripheral states.

The comparative forecast of the GDP per capita rise in the European economies show whether the European states have or do not have in the future the ability to evolve on a positive trend, starting from the reality of the previous period. The used methodology is specific to fuzzy systems, more precisely to Markov chains, starting from the GDP per capita values for a known horizon, 1997-2016, in order to get to a future one, 2017-2028.

The choice of this methodology was also determined by the fact that the forecast of some macroeconomic indicators for Romania achieved by using the Markov chains (Nicolae-Bălan, 2009) was subsequently validated by the statistical data of the INS 
(National Institute of Statistics, 2019). The paper is structured as follows: in Section 2 we briefly present the current state of knowledge through a Literature Review; in Section 3 we present the methodology used, more specifically the Markov chains. Here we describe the steps taken to achieve the forecast of European economic growth; in Section 4 we present the data and the main findings. Here we integrate the results obtained in the general European context, including the one determined by the crisis of 2020; Section 5 is dedicated to the results and discussions and, finally, in Section 6 we draw the conclusions by emphasizing the limits of research and the proposals for future analysis.

\section{Literature review}

There are many studies about economic growth and convergence, including empirical and theoretical analyses. They reach different results on this issue, according to the chosen variables, the type of data, the period of time and the empiric model used. It was demonstrated that a GDP growth rate of 3\% per year leads to an increase of the potential GDP by $10 \%$ over three years and a doubling over 23 years, which, according to the rule of 70 , implies that a growth rate of $1 \%$ per year doubles the potential GDP in a 70- year span (Angelescu and Socol, 2005). This rule, also called the rule of 69 or of 72 (as number 69 is the clearest, 70 the easiest to calculate, and 72 more precise for more modest growth rates), shows that small differences between the rates of economic growth result in big differences in the size of macroeconomic indicators (Beggs, 2019). Rule 69 (more precisely 69.3), 70 or 72 refer to the number of years required for a variable to double its value, in our case, economic growth. In the case of rule 69, in calculations the number 69 is related to the variable for which we calculate the period of doubling the value. The procedure is similar for rule 70 and rule 72. The choice is a matter of preference. Although the numbers 69 proved to be more accurate (Beggs, 2019), 70 and 72 are more easily divisible so that they became recognized. These rules are taken from the financial field.

The GDP rise is a valid measure of progress, prosperity and human well-being (Korten, 2010) and the states recording accelerated rhythms of economic growth are those with a developed industry, growth being associated to structural changes in the secondary sector (Rodrik, 2007) and industrialization stimulating the substantial changes in society and in the structure of income distribution (Sbardella et al., 2017).

The economies with a similar level of integration in the world economy have different ways to grow in the long run, according to the neoclassical models of growth. As long as the countries are not isolated from the world economy, they will grow in the long run in different manners, because this depends on the degree of integration into the global economy (London-Lane and Robertson, 2009). 
The basis of economic growth is represented by the accumulation of capital, the human capital and knowledge used in production (Persson and Tapeline, 2013). Andolfatto (2008) puts economic growth on the account of technology, technicalscientific information, human capital and management-factors that are generally available for the industrialized states. The importance of growth consists in the direct consequences on well-being and in the fact that it provides the necessary financial resources at a social level, even if the benefits of growth are unequally distributed (Smętkowski and Wójcik, 2010). Herman (2015) postulates that the process of economic growth, as it manifests itself nowadays, leads to the fall of the ecological system and affects well-being, calling even survival into question, costs being higher than benefits.

Economic growth, especially the inclusive one, is important because it reduces poverty, inequality, gender differences, it creates new workplaces, it improves the governing process and reacts to climate changes (Kireyev and Chen, 2017) involving a continuous metamorphosis. Berg et al. (2012) identify the characteristics of sustainable growth as being a more equitable distribution of incomes, democratic institutions, trade openness, direct foreign investments, a production structure that would allow a sophisticated export, a stable macroeconomic environment, with low inflation rates, with a minimal external debt and low conditions of monetary depreciation. An analysis made by Alfaro et al. (2010), starting from the idea that there is a direct influence relationship between growth and direct foreign investments, demonstrates that there is a weak support for the positive exogenous effect of foreign investments upon growth; an important fact is that the capacity of a country to benefit from the advantages that direct foreign investments provide is limited by local conditions, such as the development of local financial markets or the country's educational level. Davis (2010) finds out another causal relation for economic growth, represented by the institutional quality (the bundle of property rights) and the institutional flexibility (the ability to develop new institutions). Eicher and Schreiber (2010) identified, analyzing 26 states in transition over a period of 11 years, the positive role that change plays in the quality of structural policies or of the rule of law, because a $10 \%$ change under the OECD standards will lead to a $2.5-2.7 \%$ rise of the economic growth rate.

Forecasts of economic growth in the short run were made by means of different methods and using different indicators. The European Commission (2018), for instance, made a forecast of economic growth and reached the conclusion that, over the years 2018 and 2019, the process would evolve positively, with rates of $2.3 \%$ and $2 \%$ respectively, especially due to the expansion of consumption in the context of the emergence of new workplaces and of investments. The World Bank (2017), following a short-run forecast for the period 2017-2018, notices that production, trade, trust and the funding conditions stay favorable, so that the growth rate for 2018-2019 will be of about $2.9 \%$ at the global level, that it will reach about $4.6 \%$ in 
the case of the emergent and developing countries, but in the context of a negative trade balance, while in the Euro Zone it will record a rate of only $1.5 \%$.

The IMF (2017) speaks of a growth forecast for 2018 by a rate of about $3.7 \%$ at the world level, as a result of the positive influence of investments, trade, industrial production and trust in the business environments, while in the Euro Zone the rate will reach about $1.9 \%$, and about $4.5 \%$ in the case of the European emergent countries. With the help of regression equations, different methods were assessed to forecast economic growth in the short run for the Euro Zone on the basis of a quarterly GDP and of the monthly data, deemed much more relevant (Angelini et al., 2011). Other short-run estimations for the Euro Zone of the real GDP, using monthly data, also took into consideration indicators characterizing the industrial production except for the building trade, the new vehicle registration, the retail sales, the business environment, the consumers' confidence for the period 19902001 (Rünstler and Sédillot, 2003). The economic literature turns out to be poor in long-run forecasts of the GDP/capita growth for EU28.

The fuzzy analysis with Markov chains was introduced, in its dynamic model of growth, by Quah and Magrini, as an alternative to the standard analyses of regression (Fingleton, 1997). The fuzzy systems and the Markov chains in particular are considered by Quah (1992), a much deeper analysis compared to other long-term models of growth, and the analysis of the income per capita for 118 countries showed the instability of the models of growth in the long run in each country's case. Using the same methodology, Quah (1996) explains the dynamics of the distribution between the European regions, analyzing the incomes per capita, and concluding that they are not equal and they do not remain unchanged, because the distribution of regional incomes fluctuates over time.

Fingleton (1997) used the Markov chains starting from Quah's model, considering that the standard regression analyses lack the richness and flexibility of the Markov method. Cheshire and Magrini (1999) analyzed by means of Markov chains the determinants of growth, a complex process, for 122 urban regions in 12 western European countries in the period 1978-1994. Indicators such as income per capita, research and development activity and the role of the universities in establishing economic policies highlight the existence of divergences in the models of regional growth of the Western-European states. Le Gallo's analysis (2004) with Markov chains for the study of gaps between 138 European geographical regions in the period 1980-1995 reflects a progressive trend towards a poverty trap, as well as the importance of the geographical position in the process of convergence.

Abbasov and Mamedova (2003) applied the fuzzy logics for the simulation of the demographic process. Nastase et al. (2019) uses the theory of Markov chains to forecast the number of students enrolled in pre-university education, upper 
secondary, by groups of studies and profile. Sledge et al. (2018) proposed an uncertainty-based, information-theoretic approach for performing guided stochastic searches that more effectively cover the policy space, and Sledge and Principe (2019) provided a novel, two-part information-theoretic approach for aggregating Markov chains. Ponzio and Di Gennaro (2004) applied the methodology of Markov chains by analyzing the income per capita for 92 Italian provinces in the period 1952-1955. They found out that the Italian provinces followed different models of growth, joining, eventually, a divergent trend. Le Gallo (2004) analyzed the evolution of disparities between 138 regions in 11 European countries with the help of Markov chains, in the period 1980-1995, using GDP per capita; he reached the conclusion that the period was characterized by the persistence of regional gaps, by the absence of the relative mobility of regions in the distribution of GDP per capita, as well as by a progressive trend towards a poverty trap, while the geographical position played an important role in the process of convergence. Anas et al. (2004) used the Markov chains to study the relations between the phases of the economic cycle of industrial production in the cases of USA and of the Euro Zone. Kooros and Badeaux (2007) make, by means of Markov chains, a short-term forecast about the future market shares of companies, in the context of consumers' migration from one company to another. Monfort (2008) analyzed the regional disparities at the level of EU with the help of several methods, including Markov chains, reaching thus the conclusion that the results regarding the convergence and divergence depend very much upon the chosen method. Rey (2010) analyzed the evolution of the distribution of the national income over time - the period 1929-1944, and space - USA territory, by means of the classical Markov method, reaching the conclusion that the geographical position is important in the distribution of incomes, at least in the American case.

Soloviev et al. (2011) use the Markov chains methodology for financial time series, finding out that this is successfully applicable to researches in the financial field, and not only. The model of the Markov chains, used with good results in fields such as the regional economy for the study of inequality of incomes, sociology, microeconomics and public health, is used by Lipták (2012), to describe processes on the labor market in Hungary for the period 1992-2009. Zhalezka and Navitskaya (2015) use the fuzzy multi-criteria analysis in order to assess regional competitiveness in Belarus, and also Moosavi and Isacchini (2017) analyzed, by means of the Markov chains, series of time corresponding to the period 19952011 in order to reveal the evolution of the works economic networks, reaching the conclusion that between balance and GDP there is a relation on which future economic growth depends.

The results of the researches based on the analyses with Markov chains make us choose this method for a forecast of the GDP per capita evolution in the case of the economies of EU28 members. 
Starting from the fact that through various techniques and models, the mediumterm forecasts of the macroeconomic indicators are necessary for identifying and highlighting their positive/negative tendencies from the first manifestation phases, and they function as an early warning system, we achieved the long-term GDP per capita forecast for EU-28 member states. However, any medium-term forecast should be reassessed after a period of time (2-3 years) under the new conditions of the world conjuncture.

\section{Methodology}

We opted, as an empirical model for a forecast of EU28 economic growth, for the Markov chains, due to the results obtained in other studies we referred to.

The Markov chains represent a stochastic process according to which the probability of a random variable at a moment $t+1$ depends only on its state in the moment $t$, but not on its states in previous moments (Ponzio and Di Gennaro, 2004). The simulation of the dynamics of economic growth and of the forecast of convergence for EU28 Member States was made with Markov chains, a suggestive example for the use of fuzzy techniques (Moosavi and Isacchini, 2017; NicolaeBălan, 2009; Gherasim, 2008). The Markov chain used for the forecast study of convergence can be described as follows.

For the simulation of the GDP per capita values, we consider the period 1997-2016, which we divide into sub periods $g_{1}, g_{2}, \ldots, g_{14}$, with:

$$
\left\{\begin{array}{l}
\mathrm{g}_{1} \cong(1997,1998,1999,2000) \\
\mathrm{g}_{2} \cong(2001,2002,2003, \mathrm{~K} 2004) \\
\mathrm{M} \\
\mathrm{g}_{5} \cong(2013,2014,2015,2016)
\end{array}\right.
$$

In order to forecast values of GDP per capita for 28(+1) EU states, plus the European average, we apply the method of simulation with Markov chains with values modelled using trapezoidal fuzzy numbers. Thus, we consider the horizon:

$$
t \in\left\{\frac{\left\{1,2,3, \ldots t_{c}\right.}{\text { known }}, \frac{t_{c}+1, t_{c}+2, . ., T}{\text { forecast }}\right\}=\frac{\left\{\frac{1,2,3,4,5,6,7,8}{\text { hnown forecast }}\right.}{\text { horizon }} \begin{gathered}
\text { horizon } \\
\text { horizon horizon }
\end{gathered}
$$

where: $t_{c}$ is the last year of the known time horizon. 
The known horizon $(20$ years $)$ comprise five periods $(\mathrm{t}=5)$ of 4 years each, $\mathrm{T}_{1}=$ [1997-2000], $T_{2}=[2001-2004], T_{3}=[2005-2008], T_{4}=[2009-2012]$ and $\mathrm{T}_{5}=[2013-2016]$. For each quadruple we round the four values of the GDP per capita and order them according to Table 1.

Table 1: Rounded values of GDP per capita and their grouping in the five periods of the known horizon (Dollars per capita)

\begin{tabular}{|c|c|c|c|c|c|}
\hline $\begin{array}{c}\mathrm{t} \\
\text { GDP per capita }\end{array}$ & 1 & 2 & 3 & 4 & $5=t_{c}$ \\
\hline & 1589 & 1840 & 4676 & 8220 & 8978 \\
\hline & 1610 & 2125 & 5829 & 8297 & 9520 \\
\hline & 1668 & 2775 & 8214 & 8558 & 9585 \\
\hline & 1865 & 3553 & 10136 & 9200 & 10020 \\
\hline & 1683,00 & 2573,25 & 7213,75 & 8568,75 & 9525,75 \\
\hline
\end{tabular}

Source: Authors' calculations

A trapezoidal fuzzy number $(\tilde{a} \in N F 4)$ is a quadruple ordered like $\tilde{a}=\left(a_{1}, a_{2}, a_{3}, a_{4}\right)$, with $\mathrm{a}_{1} \leq \mathrm{a}_{2} \leq \mathrm{a}_{3} \leq \mathrm{a}_{4}$.

The values of GDP per capita of the known horizon are trapezoidal fuzzy numbers. The fifth cell of Table 1 represents the center of gravity (real number associated) and was calculated as the arithmetic mean of the 4 components, according to the relation:

$$
\mathrm{a}_{\mathrm{G}}=<\widetilde{\mathrm{a}}>=\frac{\mathrm{a}_{1}+\mathrm{a}_{2}+\mathrm{a}_{3}+\mathrm{a}_{4}}{4}
$$

The values of GDP per capita in the known horizon, expressed with trapezoidal fuzzy numbers are the following:

$$
\left\{\begin{array}{l}
\widetilde{y}_{1}=(1589,1610,1668,1865) \\
\widetilde{y}_{2}=(1840,2125,2775,3553) \\
M \\
\widetilde{y}_{t_{c}}=\widetilde{y}_{5}=(8978.00
\end{array}\right.
$$

The forecast horizon $\left\{\mathrm{t}_{\mathrm{c}}+1, \mathrm{t}_{\mathrm{c}}+2, \ldots, \mathrm{T}\right\}=\{6,7,8\}$ consists of three groups, $\left\{\widetilde{\mathrm{y}}_{\mathrm{t}_{\mathrm{c}}+1}, \ldots, \widetilde{\mathrm{y}}_{\mathrm{T}}\right\}=\left\{\widetilde{\mathrm{y}}_{6}, \widetilde{\mathrm{y}}_{7}, \widetilde{\mathrm{y}}_{8}\right\}$. The fuzzy number $\widetilde{\mathrm{y}}_{8}$ corresponds to the last group $\mathrm{g}_{8} \cong(2025,2026,2027,2028)$. The forecast of GDP per capita using (two-state) Markov chains with extreme variable (with NF4) is made in eight phases. 
In the first phase we will select the maximal level, $\widetilde{y}_{\max }$, considering annual growths of about $40 \%$.

$$
\begin{aligned}
& y_{\text {med }}=\frac{\left\langle\tilde{y}_{1}\right\rangle+\left\langle\tilde{y}_{2}\right\rangle+\left\langle\tilde{y}_{3}\right\rangle+\left\langle\tilde{y}_{4}\right\rangle+\left\langle\tilde{y}_{5}\right\rangle}{5} \\
& y_{\text {med }}=y_{\text {med }}+y_{\text {med }} \cdot 0.4 \cdot(T-t)=2.2 \cdot y_{\text {med }}=7095.54 \approx 7096 \\
& \tilde{y}_{\text {max }}=\left(y_{\text {med }} \cdot 0.80, y_{\text {med }} \cdot 0.90, y_{\text {med }} \cdot 1.10, y_{\text {med }} \cdot 1.20\right)= \\
& =(5677,6377,7806,8515)_{7096}
\end{aligned}
$$

In the second phase, we calculate the state probabilities for the known horizon, according to relation:

$$
\begin{aligned}
& \widetilde{w}_{1}(t)=\frac{\tilde{y}_{t}}{\widetilde{y}_{\max }}, t=\overline{1, t}_{c} \\
& \widetilde{w}_{2}(t)=\widetilde{1}-\widetilde{w}_{1}(t)
\end{aligned}
$$

where: $\widetilde{1}=(1,1,1,1)$ is considered trapezoidal fuzzy number.

In the third phase, we calculate, according to relations (9), (10) and Table 2, matrices with transition probabilities.

We calculate $\mathrm{n}=\frac{\left(\mathrm{t}_{\mathrm{c}}-1\right) \cdot\left(\mathrm{t}_{\mathrm{c}}-2\right)}{2}=\frac{4 \cdot 3}{2}=6$ matrices of $2 \times 2$ with elements of probabilities expressed by trapezoidal fuzzy numbers:

$$
\widetilde{\mathrm{P}}^{(\mathrm{k})}=\left[\begin{array}{ll}
\widetilde{\mathrm{p}}_{11}^{(\mathrm{k})} & \widetilde{\mathrm{p}}_{12}^{(\mathrm{k})} \\
\widetilde{\mathrm{p}}_{21}^{(\mathrm{k})} & \widetilde{\mathrm{p}}_{22}^{(\mathrm{k})}
\end{array}\right]
$$

Table 2: Matrices with probabilities of transition

\begin{tabular}{|c|c|c|}
\hline Case $\mathrm{k}$ & $\mathrm{t}^{\prime}$ & $\mathrm{t}^{\prime \prime}$ \\
\hline $\mathrm{k}=1$ & 1 & 2 \\
\hline 2 & 1 & 3 \\
\hline 3 & 1 & 4 \\
\hline 4 & 2 & 3 \\
\hline 5 & 2 & 4 \\
\hline $6(=\mathrm{n})$ & 3 & 4 \\
\hline
\end{tabular}

Source: Authors' calculations 
For each pair $\mathrm{t}^{\prime}<\mathrm{t}^{\prime \prime}$, we solve 2 systems of 2 equations with unknowns $\widetilde{\mathrm{p}}_{\mathrm{ij}}$ :

$$
\begin{gathered}
\left\{\begin{array}{l}
\widetilde{\mathrm{w}}_{1}\left(\mathrm{t}^{\prime}+1\right)=\widetilde{\mathrm{w}}_{1}\left(\mathrm{t}^{\prime}\right) \cdot \widetilde{\mathrm{p}}_{11}+\widetilde{\mathrm{w}}_{2}\left(\mathrm{t}^{\prime}\right) \cdot \widetilde{\mathrm{p}}_{21} \\
\widetilde{\mathrm{w}}_{1}\left(\mathrm{t}^{\prime \prime}+1\right)=\widetilde{\mathrm{w}}_{1}\left(\mathrm{t}^{\prime \prime}\right) \cdot \widetilde{\mathrm{p}}_{11}+\widetilde{\mathrm{w}}_{2}\left(\mathrm{t}^{\prime \prime}\right) \cdot \widetilde{\mathrm{p}}_{21}
\end{array}-\left\{\begin{array}{l}
\widetilde{\mathrm{p}}_{11}=\frac{\widetilde{\mathrm{w}}_{1}\left(\mathrm{t}^{\prime}+1\right) \widetilde{\mathrm{w}}_{2}\left(\mathrm{t}^{\prime \prime}\right)-\widetilde{\mathrm{w}}_{1}\left(\mathrm{t}^{\prime \prime}+1\right) \widetilde{\mathrm{w}}_{2}\left(\mathrm{t}^{\prime}\right)}{\widetilde{\mathrm{w}}_{1}\left(\mathrm{t}^{\prime}\right) \widetilde{\mathrm{w}}_{2}\left(\mathrm{t}^{\prime \prime}\right)-\widetilde{\mathrm{w}}_{1}\left(\mathrm{t}^{\prime \prime}\right) \widetilde{\mathrm{w}}_{2}\left(\mathrm{t}^{\prime}\right)} \\
\widetilde{\mathrm{p}}_{12}=\frac{\widetilde{\mathrm{w}}_{1}\left(\mathrm{t}^{\prime \prime}+1\right) \widetilde{\mathrm{w}}_{1}\left(\mathrm{t}^{\prime}\right)-\widetilde{\mathrm{w}}_{1}\left(\mathrm{t}^{\prime}+1\right) \widetilde{\mathrm{w}}_{1}\left(\mathrm{t}^{\prime \prime}\right)}{\widetilde{\mathrm{w}}_{1}\left(\mathrm{t}^{\prime}\right) \widetilde{\mathrm{w}}_{2}\left(\mathrm{t}^{\prime \prime}\right)-\widetilde{\mathrm{w}}_{1}\left(\mathrm{t}^{\prime \prime}\right) \widetilde{\mathrm{w}}_{2}\left(\mathrm{t}^{\prime}\right)} \\
\widetilde{\mathrm{w}}_{21}=\frac{\widetilde{\mathrm{w}}_{2}\left(\mathrm{t}^{\prime}+1\right) \widetilde{\mathrm{w}}_{2}\left(\mathrm{t}^{\prime \prime}\right)-\widetilde{\mathrm{w}}_{2}\left(\mathrm{t}^{\prime \prime}+1\right) \widetilde{\mathrm{w}}_{2}\left(\mathrm{t}^{\prime}\right)}{\widetilde{\mathrm{w}}_{1}\left(\mathrm{t}^{\prime}+1\right)=\widetilde{\mathrm{w}}_{1}\left(\mathrm{t}^{\prime}\right) \cdot \widetilde{\mathrm{p}}_{12}+\widetilde{\mathrm{w}}_{2}\left(\mathrm{t}_{2}\left(\mathrm{t}^{\prime}\right)-\widetilde{\mathrm{w}}_{1}\left(\mathrm{w}_{2 \prime}\right) \widetilde{\mathrm{w}}_{2}\left(\mathrm{t}^{\prime}\right)\right.} \\
\widetilde{\mathrm{p}}_{22}=\frac{\widetilde{\mathrm{w}}_{2}\left(\mathrm{t}^{\prime \prime}+1\right) \cdot \widetilde{\mathrm{w}}_{1}\left(\mathrm{t}^{\prime}\right)-\widetilde{\mathrm{w}}_{2}\left(\mathrm{t}^{\prime}+1\right) \widetilde{\mathrm{w}}_{1}\left(\mathrm{t}^{\prime \prime}\right)}{\widetilde{\mathrm{w}}_{1}\left(\mathrm{t}^{\prime}\right) \widetilde{\mathrm{w}}_{2}\left(\mathrm{t}^{\prime \prime}\right)-\widetilde{\mathrm{w}}_{1}\left(\mathrm{t}^{\prime \prime}\right) \widetilde{\mathrm{w}}_{2}\left(\mathrm{t}^{\prime}\right)}
\end{array}\right.\right.
\end{gathered}
$$

In the fourth phase, we verify the conditions of positivity. The components of the matrices $\widetilde{\mathrm{P}}^{(\mathrm{k})}, \mathrm{k}=\overline{1, \mathrm{n}}$ are probabilities. Therefore, they will verify 2 conditions reflected in next relation:

$$
\left\{\begin{array}{l}
<\widetilde{\mathrm{p}}_{11}^{(\mathrm{k})}>+<\widetilde{\mathrm{p}}_{12}^{(\mathrm{k})}>=1 \\
<\widetilde{\mathrm{p}}_{21}^{(\mathrm{k})}>+<\widetilde{\mathrm{p}}_{22}^{(\mathrm{k})}>=1
\end{array} \text { and } 0 \leq<\widetilde{\mathrm{p}}_{\mathrm{ij}}^{(\mathrm{k})}>\leq 1\right.
$$

In this phase, we will eliminate the matrices that do not meet conditions (11). If none fulfils them, we go back to the first phase and choose a different value $\widetilde{\mathrm{v}}_{\max }$.

In the fifth phase, we select the most homogenous transition matrices. For each matrix $\widetilde{\mathrm{P}}^{(\mathrm{s})}, \mathrm{s} \in \mathrm{S} \subseteq\{1,2, \ldots, \mathrm{n}\}=\overline{1, \mathrm{n}}$ we calculate the distance between the elements, based on relation:

$$
\mathrm{d}^{(\mathrm{s})}=\left(<\widetilde{\mathbf{p}}_{11}^{(\mathrm{s})}>-<\widetilde{\mathrm{p}}_{12}^{(\mathrm{s})}>\right)^{2}+\left(<\widetilde{\mathbf{p}}_{21}^{(\mathrm{s})}>-<\widetilde{\mathrm{p}}_{22}^{(\mathrm{s})}>\right)^{2}
$$

The most homogenous matrix has the smallest distance between elements:

$$
\widetilde{\mathrm{P}}=\widetilde{\mathrm{P}}^{(\mathrm{o})} \text { so that } \mathrm{d}^{(\mathrm{o})} \leq \mathrm{d}^{(\mathrm{s})}, \forall \mathrm{s} \in \mathrm{S}
$$

The values of the indicators in the forecast horizon are obtained for each of the years. We set the temporal variable with the first year of the forecast, $\mathrm{t}=\mathrm{t}_{\mathrm{c}}+1$ and the probability of initial state for the forecast horizon:

$$
\widetilde{\mathrm{P}}_{\mathrm{t}_{\mathrm{c}}}=\widetilde{\mathrm{w}}_{1}\left(\mathrm{t}_{\mathrm{c}}\right)
$$

Phases $6,7,8$ are followed for all the forecast years, $t=\overline{t_{c}+1, T}$.

In the sixth phase, we calculate the state probabilities, based on the relationship (15), for the year $t$ of forecast:

$$
\widetilde{\mathrm{P}}_{\mathrm{t}}=\widetilde{\mathrm{P}}_{\mathrm{t}-1} \cdot \widetilde{\mathrm{p}}_{11}+\left(\widetilde{1}-\widetilde{\mathrm{P}}_{\mathrm{t}-1}\right) \cdot \widetilde{\mathrm{p}}_{21}, \quad\left(\mathrm{t}=\overline{\mathrm{t}_{\mathrm{c}}+1, \mathrm{~T}}\right)
$$


In the seventh phase, we evaluate the maximal level for year $t$ of forecast, according to relation:

$$
\tilde{\mathrm{y}}_{\max }(\mathrm{t})=\widetilde{\mathrm{y}}_{\max }+\frac{\widetilde{\mathrm{y}}_{\max }-\widetilde{\mathrm{y}}_{\mathrm{t}-1}}{\mathrm{~T}-(\mathrm{t}-1)}
$$

In the eighth phase, we calculate GDP per capita (fuzzy number) for year $t$ :

$$
\widetilde{y}_{t}=\widetilde{y}_{\max }(t) \cdot \widetilde{\mathrm{P}}_{\mathrm{t}}
$$

For the interpretation of the results, we calculate the real numbers associated to the values of the forecasted values (fuzzy numbers).

\section{Empirical data and analysis}

The analysis of economic growth for EU28 members using Markov chains consists in the forecast of the phenomenon starting from the known horizon (1997-2016) for a forecasted horizon (2017-2028). Considering that the values of the growth indicator are final for the year 2016 (for 2017 are semi defined data and for 2018 are provisional data), we considered that the forecasted horizon had 2017 as a limit. The values of GDP per capita, the indicator we deemed suggestive for a description of the economic growth process, specific to the known horizon, were taken from the World Bank bases and are expressed in dollars (World Bank, 2017).

The known horizon, spanning 20 years, was divided into five intervals of four years each (T1:T5). The forecast horizon, spanning twelve years, was divided into three periods of four years each (T6:T8).

The 28 EU Member States, including the EU28 average as an entity by itself $(+1)$ were divided, according to the decreasing value of the GDP per capita recorded in 2016, into three groups:

- the states with a high economic growth including 9 Member States: Luxemburg, Ireland, Denmark, Sweden, the Netherlands, Austria, Finland, Germany and Belgium - a group we designate as A, the highest speed states;

- the states with moderate economic growth, including 10 Member States: UK, France, Italy, Spain, Malta, Cyprus, Portugal, Estonia, Lithuania, Poland - a group we designate as B, the average speed states;

- the states with a modest, peripheral economic growth, including 9 Member States: Slovenia, Czech Republic, Greece, Republic of Slovakia, Latvia, Hungary, Croatia, Romania, Bulgaria - a group we designate as $\mathrm{C}$, the low speed states. The third group of growth was designated as the old periphery, as it contains the states with the poorest growth results in 2016. We opted to keep UK in the analysis, as it theoretically preserves its status as a Member State. 
Before presenting the results we have obtained, it is necessary to describe the European economic picture with a focus on the countries of Central and Eastern Europe, which, in fact, are the ones put in the situation to reduce the development gaps. After the change of the economic system, the countries of Central and Eastern Europe went through periods characterized by similarities. Bulgaria, Croatia, Estonia, Hungary, Latvia, Poland, Romania, Slovakia and Slovenia have applied different economic reform measures in their way to the market economy. The focus was on different sectors, and the speed of implementation of reform measures was very different. The stated goal was to reduce the gaps with the European developed states. Havrylyshyn et al. (2018) talk about European countries that implemented reforms in the early stages of their post-communist development and about countries that implemented reforms gradually. Havrylyshyn et al. (2018) divide European countries, relative to the speed of implementation of economic reforms, into several groups. These groups are Sustained Big-Bang (Estonia, Latvia, Lithuania, Czech Republic, Poland, Slovakia), Advanced Start/Steady (Croatia, Hungary and Slovenia), Aborded Big-Bang (Bulgaria along with other non-EU states), Gradual Reforms (Romania along with other non-EU states) and Limited Reforms (group to which no country in our interest group belongs).

During the transition period, these European states went through processes of economic, institutional and social transformation. Adnanes (2007) explained that, after the 1990s, the states of Central and Eastern Europe went through periods of imbalance that generated economic divergence on a recessionary background characterized by inflation, declining production, worsening social inequalities and unemployment (Estrin and Mickiewicz, 2010; Sykora and Bouzarovscki, 2011; Rovelli and Zaiceva, 2013).

The reform measures undertaken in the period following the change of the economic system have left their mark on the subsequent economic evolution, which we also tried to prove in this research. The performances on the line of economic growth and convergence towards the developed European states depend on the start taken in the 1990s. In countries like Poland, the Czech Republic or Slovakia, the "shock therapy" has affected the economy and the quality of people's lives. These countries have gone through transformational crises that have manifested themselves in declining industrial production, rising inflation, declining real incomes and the purchasing power of money. For example, the Czech Republic and Lithuania have opted for rapid privatization. In these countries the privatization process took place in only four years, 1991-1996 (Spicer et al., 2000). Romania and Hungary have opted for a gradual privatization process, carried out from close to close. Economic instability was, according to Spicer et al. (2000), more pronounced in Poland, lower in the Czech Republic, Slovakia and Hungary, while Romania and Bulgaria are in an intermediate 
position. The Czech Republic, Hungary, Poland and later Slovakia and Hungary reduced the secondary sector and successfully developed the tertiary sector. Romania and Bulgaria have counterbalanced the contraction of industry with a slight expansion of agriculture (Zanewska and Mickiewicz, 2006). Croatia and Slovenia enjoyed favorable initial conditions due to a low degree of centralization prior to their transition period. The Czech Republic, Slovakia, Poland, Hungary, Estonia, Lithuania and Latvia have managed to complete the transition period ahead of other European states. Dabrowski (1995) considers Poland to be the European leader in the reform process, seconded by Slovenia.

An analysis of GDP per capita in the EU conducted by Haller (2020) confirms the aspects already mentioned but also the results of this research. The European average GDP increased 2.4 times in the period 1980-2016. Croatia, Czech Republic, Hungary, Romania, Latvia, Lithuania and Slovenia have managed to increase the value of GDP per capita more than twice but below the European average. The only countries on the European periphery that have managed to outperform the average European performance are Estonia, Poland and Slovakia. Developed countries, in their dynamism, maintain the economic gaps on European territory. Thus, we were interested in the extent to which in the future there is the possibility of reducing economic discrepancies in caeteribus paribus conditions.

Along the forecast horizon, in the context of an ascendant GDP per capita, the gaps between the groups of EU28 member states grow deeper. A relative convergence is maintained within each group of growth. The largest gaps will be recorded between the first (A) and the last (C) group of development. Considering the first group, including the countries with a significant GDP per capita growth, which is specific to high-speed European states, as a dynamic group, economic divergence is justified even under the circumstances of a rise of GDP per capita value for the Member States of group B and C (Figure 1). 
Figure 1: Evolution of GDP per capita over the time horizon known and forecast, in the Member States

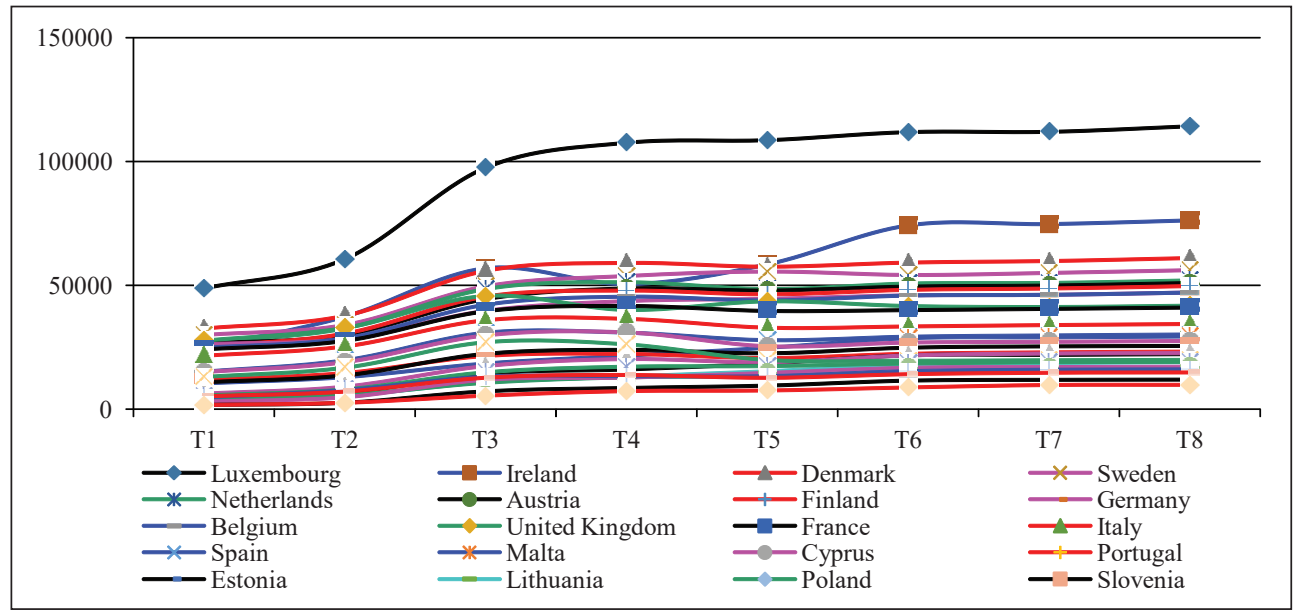

Source: Author`s calculations

The average GDP per capita for each of the three European growth groups is presented in Figure 2. Group B loses $2.3 \mathrm{pp}$ (during the 12 forecasted years) from the differences in the GDP per capita value compared to group A, which demonstrates a slowdown in the convergence process between group B and group A states. Group C recovers (during the 12 forecasted years) from the differences in the GDP per capita value compared to group $\mathrm{A}$ and $\mathrm{B}$, with $5.45 \mathrm{pp}$, respectively $2.7 \mathrm{pp}$.

Figure 2: Evolution of average GDP per capita over the time horizon known and forecast, groups of Member States

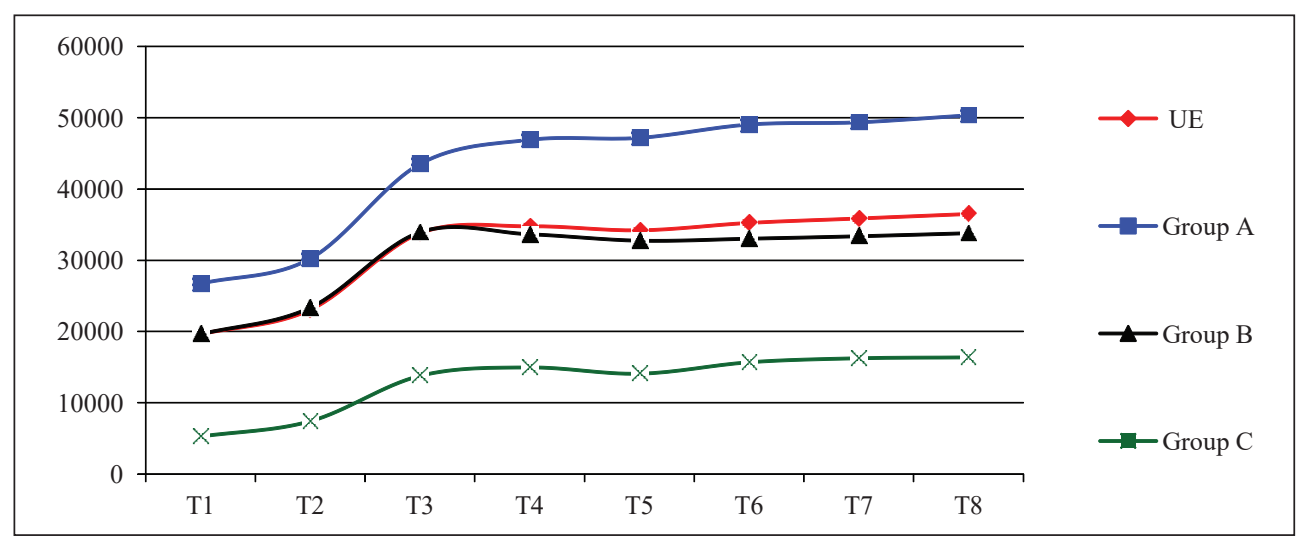

Source: author`s calculations 
The GDP per capita growth from T5 to T6 for the Group A countries was higher because, besides the fact that these are solid economies which, through the policies and measures adopted have more easily faced the challenges created by the recent economic and financial crisis, they also recorded high values of labor productivity by increasing the participation in the labor market, both of the native population, as well as by the presence of workers from abroad.

Uncertainties about Britain's position in the European Union after Brexit have led a significant number of companies to move their UK headquarters to some Group A countries, as a possible basis for the European market, which has contributed to their GDP growth.

The simulation using Markov chains is illustrative for how development gaps within EU28 (+1) intensify by 2028. The fuzzy analysis starts from a known horizon, during which the global and the national economies crossed the most serious crisis of the 2000s, a period of many economic and social challenges for most of the Member States.

Luxembourg will remain, in the next three decades, the European state with the best economic results reflected in the GDP per capita value. Ireland remains one of the leader countries, with an economic growth much beyond the level of the other members. The forecast reveals that in 2028 the GDP per capita value for this country will be 3 times bigger than at the beginning of the period considered. According to the Markov chain forecast, in some Western and Northern European countries, GDP per capita will increase 3-4 times, compared with the beginning of the period.

Another group of states is made of those members whose GDP per capita will be double or will at least increase in 2028 compared to the beginning of the forecast period. We forecast that Austria, Belgium and Spain France will manage to go on a positive trend without reaching the results of the states from the first group, doubling the value of GDP per capita. Malta, Poland, Slovenia, Hungary, Czech Republic and Croatia will be able to increase the GDP per capita value, reaching triple values compared to the forecast starting year; they are buffer-states between the periphery and the rest of the European states.

The third group of states is made up of Estonia, Lithuania, the Czech Republic, Latvia, Romania and Bulgaria.

Following the forecast with Markov chains, we find out that the EU28 periphery in 2028 will be somehow different, as the Slovak Republic, Estonia, Czech Republic, Latvia, Lithuania, Croatia and Hungary will manage to go towards the center, reaching a higher convergence degree, Slovenia, Greece, Romania and Bulgaria will preserve their status of peripheral European countries. 
The average economic growth of EU28 will be modest in 2028. The GDP per capita of EU28 will rise at the end of the forecasted period by less than $1 \%$ compared to 2016. The forecast reflects clearly that inside the EU, the gaps will not disappear and they will even intensify in the periphery, especially in the case of countries such as Romania and Bulgaria and the accession of other countries of the former Yugoslavia.

Comparative analysis of the forecast made by using Markov chains indicates that in 2028, economies such as Italy, Spain, Malta, Cyprus, Greece, Estonia, Lithuania, Slovenia, the Czech Republic, Latvia, Hungary, Croatia, Romania and Bulgaria will record values of GDP/capita under the average of EU28. The only states from the old periphery that have chances to converge economically with the European mean will be Czech Republic and Slovakia. The rest of the states from the old periphery and especially those of the new periphery, particularly Bulgaria and Romania, will maintain significant gaps compared to the European average, especially the latter.

The core of the EU28 economic growth will record high rhythms of GDP per capita. Luxembourg will remain, compared to the other Member States, the country with the highest rate; the only states with a higher growth rhythm will be Germany and UK. The most significant gaps favoring Luxembourg can be noticed in relation to the peripheral and to the buffer states: Romania, Bulgaria, Latvia, Estonia, Lithuania, Greece and the Czech Republic. In the case of the new periphery, the gaps to Luxembourg will intensify in the horizon of the years 2028, an aspect noticed in the analysis using Markov chains, especially in the case of Bulgaria and especially of Romania.

If we refer to Ireland, Denmark, Sweden and Finland, we see that these countries have a positive economic evolution compared with other states. We notice the maintenance of the gaps between the old and new periphery. For Central and Eastern Europe it will be hard to reduce the economic growth gaps compared to countries like the ones we mentioned. The Danish economy will progress in tandem with the average growth rate of EU28, Sweden will record a higher economic growth than the majority of the Member States, Ireland will have a positive evolution compared to some countries such as Cyprus, Lithuania, Poland, Greece, Hungary, Croatia, Romania and Bulgaria, and Finland will have a growth rate slightly higher than the EU28 average. This group of countries is developed, with superior economic performances to other Member States, focused on services in high-tech, life science, finance, foreign direct investment flows (Ireland), on services and foreign trade (Finland), on high level of government services and foreign trade (Denmark and Sweden). The growth projections of OECD (2020) show that economy of this group of countries will recover in 2021 and expand in 2022. Ireland's economy will grow in 2022 at over $4 \%$ based on investments, domestic demand and public sector support. The economy of Finland will expand by around 1.5\% in 2021 and $1.75 \%$ in 2022 based on investments. The Danish economy growth will be gradual 
of nearly $2 \%$ in 2021 and $2.5 \%$ in 2020 and the Swedish economy is expected to expand by $3.3 \%$ both in 2021 and 2022. These projections of OECD (2020) made after our forecast come to support our results even if our analysis did not anticipate such a risk as that of 2020 .

Netherlands, Austria, Belgium, UK belong to another group of European countries. In the case of Netherlands we notice progress in gaps reduction in the cases of Czech Republic, Latvia, Lithuania and Slovak Republic. The growth rate of Austria and Belgium will be higher than the EU28 average and higher than that of many other Member States. Even so, Greece and the Slovak Republic will manage to converge economically with Austria and Latvia, and the Czech Republic and the Slovak Republic with Belgium. The entire new periphery will remain divergent economically to Belgium. UK's economic growth is forecasted to be much beyond the EU28 average and over the majority of the Member States. Again, we discuss about countries with very good economic performances. Netherlands has an economy based on foreign trade and one of the highest-earning nation in the world. Austria has one of the richest economy in the world in terms of GDP with an increasing international competitiveness level and Belgium is a country with an excellent infrastructure and with an economy based on re-export that depends heavily on world trade. Regarding UK, this country has one of the largest economy in the world reported to nominal GDP, is one of the largest traders in the world and is based on foreign direct investments being dominated by the service sector. OECD (2020) made projections regarding this group of countries. Netherlands`s GDP was set to fail by $4.6 \%$ in 2020 , Austria`s by $8 \%$, Belgium`s GDP by $7.5 \%$ and UK's GDP by $11.2 \%$. OECD (2020) projects the rise of growth rate with $0.8 \%$ and $2.9 \%$ in 2021 and 2022 in the case of Netherlands, and a gradual rise bellow its pre-crisis level in the case of Austria. In the case of Belgium it is estimated a slow recovery starting with 2021 and UK will grow with a rate of $4.2 \%$ in 2021 and $4.1 \%$ in 2022 . Moderate investments, consumption and public interventions will help these countries to revigorate.

Referring to so called Mediterranean countries, Italy, Spain, Malta, Cyprus, Greece and Portugal, our forecast shows, in Italy's case convergence with the more developed states and, at the same time, divergence with other economies; in the case of Spain only Czech Republic and Slovak Republic will economically converge with it and with Malta and Cyprus and, for Portugal and Greece the forecast reveal a lower growth than the developed European states. Italy is the third largest European country by nominal GDP and one of the largest in the world by exports, its well known for its tourists sector, like other Mediterranean countries, but even so, the country suffers from structural and non-structural problems. Spain is the fifth largest European country and, after the crisis in 2008, the Spain economy begun to recover, especially the labor market and labor productivity, the international trade because Spain significantly reduced imports and increased exports, and tourism. 
Malta, Cyprus and Greece have a service and innovation based economy, especially Malta. In the case of Portugal, the economy has been steady but expanding continuously since 2014, with a continuous fall of the unemployment rate. For these group, OECD (2020) make positive projections. Italy, after falling sharply in 2020, will expand the economy with $4.3 \%$ in 2021 and with $3.2 \%$ in 2022 on the base of investments and exports and, in a very small extend on the job creation especially for the low-skilled women and youth. For Spain, GDP will grow by 5\% in 2021 and 4\% in 2022. In the case of Portugal, the fall in 2020 was by $8.4 \%$ but, starting with 2021 , the recovery will be by $1.7 \%$ and $1.9 \%$ in 2022 . The economy of Greece will contract with $10 \%$ in 2020 and the recovery will be gradual, based on services, exports, employment and investment. For this country, the projection for 2022 predicts an accelerated growth. In the cases of Malta and Cyprus we have no predictions from OECD. It is seen that OECD projections sustain our findings in the case of Mediterranean countries.

If we take in consideration Germany and France, the leading drivers of European economy, a part of European states will record an economic convergence with them but not the peripheral ones. No country from the old and the new periphery will manage to reduce growth gaps to Germany, while the biggest differences will be seen in Romania and Bulgaria's cases. Germany is one of the largest exporters in the world and has a well developed service sector but also Germany is one of the largest manufacturing economy globally. At its turn, France is the second European engine. Its economy will grow by a higher speed than the peripheral states, except Czech Republic and Slovak Republic which will follow a convergence process with the former economy. The new periphery will maintain or will accentuate the economic divergence with France, while Bulgaria and Romania will be characterized by chronic gaps. France has a diversified economy dominated by service sector and is the fifth largest trading economy in the world and the second in Europe after Germany. Also it is the third European manufacturing European country after Germany and Italy. In the case of these two leading countries we notice the contraction of GDP in 2020 but the projections of OECD (2020) show the ascending cadence starting with 2021 . The German economy will contract by $5.5 \%$ in 2020 because of falling of private consumption, business investment and exports. In 2021, growth will be by $2.8 \%$ and in 2022 by $3.3 \%$ on the base of a rapid rise of consumption and exports. In the case of France, the fall will be by $9.1 \%$ in 2020 but the economy will expand by $6 \%$ in 2021 and $3.3 \%$ in 2022 . We see that these results of OECD sustain our forecast.

The last group to which we refer consists of the states that represent the center of interest for our analysis: Czech and Slovak republic with the highest chances of convergence, Estonia, Poland, Slovenia, Latvia, Lithuania, Hungary, Croatia, Bulgaria and Romania. Estonia and Lithuania are countries with a lower growth than the European average. Poland is the country of the Central and Eastern Europe with the most spectacular economic evolution. The change of system took place 
in about the same period as the other former socialist states of Europe. The GDP per capita value in 2016 places it in the group of states with an average speed of growth, without being a peripheral state. The forecast made by 2028 demonstrates Poland's capability to reach economic convergence with most of the Member States, while gaps are maintained with the developed European countries. At the end of the forecast period, Poland will record a GDP per capita value well below the EU28 average. Slovenia, a country of the old periphery, will undergo a process of convergence able to help the economy go beyond the status of peripheral country, but the gaps with most of the Member States will remain, including with the EU28 average. For Slovenia, the forecast shows GDP per capita values higher than Estonia, Lithuania, the Czech Republic, Croatia, Bulgaria and Romania. Latvia and Slovakia will preserve gaps with the developed Member States but, in their turn, will let behind them states from the periphery, especially Romania. Latvia will maintain gaps with most the European states, even if at a low level, with a GDP per capita value under the EU28 average. In the case of Hungary, a country of the old and new periphery, the process of convergence consists in a large gap in relation to most of the European states, including in relation to the EU28 average. Between Romania and Hungary, the gaps will be accentuated. Croatia will record a GDP per capita value under the EU28 average and the average of the developed states. The largest gaps will be those between the Croatian and the Romanian economies, in favor of the former. Bulgaria, a country whose economy evolved in tandem with Romania's economy and situated in a territorial proximity, will easy detach itself from Romania by its economic growth results. From the description of these economies we notice the progress that all have made especially after the accession to EU. Czech's economy is export oriented, based on services, manufactures and innovation, with an industrial sector that accounts $37.5 \%$ of GDP, while services accounts $60 \%$ of GDP. The growth of the country is focus on research and development, software and nanotechnology, among others. The GDP of Slovakia grew strongly after from 2000 and 2008 based on foreign direct investment, on skilled labor and on services. Estonia has an economy heavily influenced by the developments of the Finnish and Swedish economies, Lithuania has the largest economy among the Baltic states, Latvia has an economy based on service sector and a strong export sector, Slovenia has a service based economy, Poland is the country with the most remarkable performances among the former Eastern Bloc, Hungary has an export oriented economy, with a high accent on foreign trade, Croatia has one of the strongest economies in Southeast Europe where tourism is an important contributor to GDP and Bulgaria and Romania have, despite all the difficulties which they faced, made economic progresses, Romania being a leading destination in Central and Eastern Europe for foreign direct investment. However, these two countries are failing to catch up, especially with European developed economies at a sufficiently high level as they would like. For all group of countries, OECD (2020) projected the fall of growth rate in 2020 and the recovery after. The fall is set like it follows: $6.8 \%$ for Czech Republic, 6.3\% for Slovak republic, $4.7 \%$ 
for Estonia, a relatively mild contraction for Lithuania, 4.3\% for Latvia, 7.5\% for Slovenia, $3.5 \%$ for Poland, $5.7 \%$ for Hungary, $4.1 \%$ for Bulgaria and 5.3\% for Romania. Starting with 2021 and 2022 the recovery of growth will be slowly for Czech Republic, around $2.7 \%$ and $4.4 \%$ for Slovak Republic, by $3.4 \%$ and $3.3 \%$ in 2022 for Estonia, by 3\% in both 2021 and 2022 for Lithuania, by 2.4\% and $4 \%$ for Latvia, $3.4 \%$ in average for Slovenia and in this case the growth will be based on investments and exports, by $2.9 \%$ and $3.8 \%$ for Poland, by $3 \%$ in average for Hungary, $3.3 \%$ and $3.7 \%$ for Bulgaria and $2 \%$ and $4.4 \%$ for Romania. If we take into account the estimations of OECD (2020) they support those of our study even if the analysis we made did not start from the idea of a such risk like current crisis. Our analysis and the OECD (2020) one are projections based on different hypotheses. These may or may not come true like any probability. Our predictions start from the premise that all conditions before 2020 remain constant because it was achieved before the Covid-19 crises, and that of OECD starts from the reality of the year 2020. Although statistics prove the strong economic and social impact of the Covid-19 crisis. Both forecasts provide the ability of the European economies to recover. Both results show that developed economies have a higher capacity for recovery compared to less developed ones, which certainly puts the new periphery in an inferior position but demonstrates the ability of all European states to resume growth in a short period of time maintaining the gaps between them.

Romania is a particular case. The forecast using Markov chains presents a country which, in the long run, will undergo a convergence process so slow that the growth gaps not only will not be reduced, but will be significantly intensified. Practically, in the 2028 horizon, Romania will record the largest growth gaps compared to the rest of the European Member States. The GDP per capita values in the period 19972016 (20 years, first 5 groups) are according to Table 3.

Table 3: GDP per capita values for Romania in the period 1997-2016

(dollars per capita)

\begin{tabular}{|c|c|c|c|c|c|c|c|c|c|}
\hline Year & GDP/capita & Year & GDP/capita & Year & GDP/capita & Year & GDP/capita & Year & GDP/capita \\
\hline 1997 & 1589,01 & 2001 & 1839,73 & 2005 & 4676,32 & 2009 & 8220,11 & 2013 & 9585,27 \\
\hline 1998 & 1864,99 & 2002 & 2124,87 & 2006 & 5828,75 & 2010 & 8297,48 & 2014 & 10020,28 \\
\hline 1999 & 1610,13 & 2003 & 2774,96 & 2007 & 8214,19 & 2011 & 9200,28 & 2015 & 8978,39 \\
\hline 2000 & 1668,16 & 2004 & 3552,92 & 2008 & 10136,47 & 2012 & 8558,40 & 2016 & 9519,88 \\
\hline
\end{tabular}

Source: https://data.worldbank.org/indicator/NY.GDP.PCAP.CD

In the known horizon, the GDP per capita value increased about 6 times, but this proved not to be a guarantee for a real convergence in the long run. Romania's economic delay is and will be caused by a bundle of factors such as, for instance: the little evolved socio-economic structure; one of the most numerous rural populations 
in Europe (Boia, 2012); political instability; a more and more numerically reduced elite with no decision-taking power; expired educational and medical systems; a diminished cult of work compared to other societies (Haller, 2011); a need to learn and to borrow knowledge from abroad, to always be in the others' "trailer"; as a EU member, Romania proves to be a rather mediocre entity, with no personality or initiatives, accepting what the others decide, being a fragmented, atomized country that does not manage to identify its own profile, maybe because it does not have one (2011). Making an analogy with what Thomas Friedman (2008), considered to be the objective of the developing countries, Romania is searching for comfort for a larger and larger part of its population, while being incapable of providing it in the next 30 years, even if social inequality is, on the whole, immoral and unjustified. Romania is one of the developing countries whose growth is mainly supported by its natural sources (McNabb and Le May-Boucher, 2014), and consumption, factors which are generally unsustainable, as shows the forecast using Markov chains.

The forecast for the next 12 years (2017-2028) reveal the economic convergence of the European states, but this is not harmonious, it does not reveal a whole, and not the same rhythm. EU28 will continue to evolve to different speeds. There will be situations in which convergence will be so slow that it will be negligible. At the horizon of the year 2028, the periphery will suffer modifications in the sense of its reduction, as the Czech Republic and the Slovak Republic will go out, managing to converge with most of the developed Member States. The Slovak Republic, Latvia, Hungary, Croatia will progress towards the center, following a process of convergence, without reducing significantly the gaps with all developed states. The leader European countries remain Luxembourg, Ireland, Germany and UK while those with the lowest results (convergence very low) remain Bulgaria and Romania. Romania will be the Member State with the poorest perspectives to reduce growth gaps. It will not only stay in the periphery group, but the economic convergence will be so slow, that gaps will intensify significantly, according to the forecast using Markov chains, including in relation with Bulgaria, though this is in its turn a peripheral country.

\section{Results and discussion}

Sustainability is a broad concept applied to a wide range of situations, in very different contexts, whose main feature is its long-term manifestation. The temporary component of sustainability resides in its dynamics during the production and consumption processes. As the effects of production and consumption on the environment and ecosystem manifest themselves over time, we characterize growth and implicitly development as sustainable after a gap between the moment of production and consumption and that of the actual manifestation of effects. Growth is the effect of industrialization and we notice the time elapsed between 
the moment of the first industrial revolution and the manifestation of the negative effects of industrialization. For this simple reason, we must ensure a long-term, sustainable growth. Globally, efforts are being made to ensure the growth of prosperity in a sustainable way, so that the growth will take place in tandem with good resource management. Sustainability, in the long term, will be achieved as the main objective, as risks such as climate change, limited resource manager, hunger, poverty, income inequalities, urbanization, crises, will be diminished if not even eradicated. Sustainability is, without a doubt, a concept that refers to a dynamic movement in time of economic and social processes, including economic growth. This is the reason why an analysis of the economic growth implies a vision of perspective in the medium to long and even very long term. The growth, in the long and very long term, will only be sustainable so that the associated risks will not increase in intensity and their effects can no longer be managed.

The analysis using Markov chains shows that a process of convergence will take place inside each of the groups. All the EU28 Member States will progress with very different speeds, so that they will be situated on convergent or divergent trends in relation to the developed economies, to the European average, and to each other. A significantly divergent trend is noticed in the case of the peripheral countries, which will affect even the average economic growth of EU28. If between the groups $\mathrm{A}$ and $\mathrm{B}$ we forecast a reduction of the growth gaps (convergence), between the groups $\mathrm{C}$ and $\mathrm{B}$ and $\mathrm{C}$ and $\mathrm{A}$, they will grow slightly larger in the first case, and more significantly larger in the second (divergence).

In the paper we showed that, despite the constant efforts made by the states in group $\mathrm{B}$ and $\mathrm{C}$, the gaps between European countries are maintained. Although we have the evidence of nominal convergence, the gaps remain, mainly for the peripheral states. We have noticed that the countries in group B also continue to be below the average of European performance. This aspect demonstrates that the economic redundancy exists despite some economic developments. We note the lack of the long-term growth sustainability in the case of some European countries namely from our group C. This leads us to the conclusion that, following the ascension to the European Union, the recommended economic recipe for these countries was not fully efficient or the internal obstacles for its correct application are far too great to be successfully escalated. In this context, having the scientific proof of maintaining the European development gaps between the periphery and the center on the background of a slight convergence, we see and recommend that the solutions to be found in the application of economic policy measures. The model applied by Poland and Hungary appear as a plausible solution. It becomes necessary for each of the peripheral states to reevaluate their own comparative and competitive advantages. Also, to reevaluate its full economic and social potential. If these states seek to achieve a real convergence, not just a nominal one, they must reduce their external dependence on two paths. One that targets economic policy measures. 
One that targets the economy and society. The first path involves the adoption of realistic and effective cyclical and structural policies. Strengthening the secondary sectors, increasing internal and external competitiveness are desirable objectives for achieving real convergence. The efficiency of export production is possible only by increasing the external competitiveness and selling abroad products with high added value. Investment policy plays an important role in the convergence process. The priority given to domestic investments, the support given to investors and the stimulation of the innovational process also contribute to the possibility of narrowing the center-periphery distance. An important economic issue for helping or hindering the sustainable growth in the future is the energy security and the use of renewable resources and this is a big challenge for some European states.

The economic reality of each country is complex and hence the difficulty of applying common measures. The same complexity keeps us from formulating a unique recommendation with the pretension of being efficient. For each of the groups B and $\mathrm{C}$ countries, once scientifically confirmed, the existence of gaps between them and European center becomes important for the analysis of its own situation, following that this will determine the framework for taking adequate measures.

Our research is a general one on the evolution of European economic growth in the medium term. We notice the maintenance of some economic nature problems without being able to determine the causality in each case or at the level of a specific analyzed group. The paper is a basis for future research to analyze the evolution of macro indicators in relation to certain influencing factors. Even so, the complexity of the phenomenon would still leave many aspects uncovered. We noticed that, despite a nominal convergence, the real one is expected in time. In the medium term, some European countries continue to lag behind others in terms of economic progress. Each of the analyzed countries must find the cause of this situation and improve its economic and social situation through particular economic policy measures.

The paper confirms the results of studies such as those of Iancu (2009), Smętkowski and Wójcik (2010), Haller (2020) and others. We showed in the paper that the peripheral European states, in caeteris paribus conditions, have the capacity of economic nominal convergence. However, there are countries that won't be able to close the development gaps and these will increase. The paper completes the specialized literature and brings the novelty of the grouping of European states according to other criteria than the classical ones, namely that of the periphery. We used a less common methodology in similar studies to be able to draw conclusions with forecasting titles. Of course, there are limits of research. Some have to do with the time interval researched, others with the methodology, others with the criteria for classifying the states in the focus group. Orientation to other temporary intervals, especially future ones, the use of another methodology, other macro indicators or variables analyzed may lead to results that contradict or support those obtained in this research. 
Even the resuming of the methodological process only by extending the temporary horizon after 2020 can be surprising by results.

We consider the conclusions of research valuable through their usefulness. Not only do they strengthen the results of other scientific approaches but they also provide a theoretical basis for future research but also an inspirational basis for making macroeconomic decisions for the development of European states, especially in Central and Eastern Europe.

Starting from the research results, we found that, in the medium term, the gaps in the European perimeter are not reduced. They will be maintained and even accentuated. The research draws attention to the fact that there are problems that persist for at least the next 8 years. Additional analyzes are needed in which a complex of variables is linked in order to be able, in each case, to partially determine the causality of the lack of real convergence. This allows the development of concrete solutions.

\section{Conclusions}

In the present research we started from the hypothesis that, in the period 19972016, the European countries, especially the ones from Central and Eastern Europe, went through a period of economic growth, and the trend will be maintained in the future with the specification that development gaps will be continuously reduced. In this sense, we have made a forecast until 2028 with the help of Markov chains.

The results we have reached show that this group of states has gone through a process of nominal convergence but not through a process of real convergence. This last aspect is demonstrated by the existence and maintenance of gaps between the periphery and the center formed by the developed economies of EU. The hypothesis that by 2028 the less developed European countries will reduce the gaps compared to the developed ones is refuted. European convergence is slow and, in the case of some countries we have classified in the category of peripheral ones, by emulation. This shows the existence and maintenance of economic dysfunctions and draws attention to the fact that they must be notified and resolved. The results of the research show that the change of the economic system, although it might be beneficial, did not attract the desired effects in economic and social field. Even though remarkable progress has been made, the economies of the former communist states have failed to provide their population with a standard of living comparable to that of developed European countries. And this inability will continue, at least until 2028. According to Mill's paradox, there were expectations of spectacular leaps in the economic evolution of some European states. We have shown that this not only has not happened but will not happen in the short and medium term. Through our analysis we noticed that, on a positive growth trend, the gaps will be maintained. We have opened the way to find the causes of this situation that can differ substantially from country to country. 
Future research, based on other methodologies, variables, time periods will further clarify the causal aspects. Future research based on Markov chains but on other period of time will demonstrate the correctness of the present scientific approach. Our analysis signals the non-fulfilment of a major objective of some European states, to align in terms of the conditions offered to the population with developed countries, which will be maintained over time. We also recommend rethinking the strategic mix and economic policy measures in the case of each country in relation to specific economic and social conditions.

\section{References}

Abbasov, A.M., Mamedova, M.H. (2003) "Application of Fuzzy Time Series to Population Forecasting", Vienna University of Technology 2003, Issue 1, pp. 545-552, Available at: <http://papers.cumincad.org/data/works/att/50b1.content. pdf $>$ [Accessed: May 3, 2019].

Ådnanes, M. (2007) "Social transition and anomie among post-communist Bulgarian Youth", Young, Vol. 15, No. 1, pp. 49-69, doi: 10.1177/ 1103308807072684. [Accessed: November 3, 2020].

Alfaro, L. et al. (2010) "Does Foreign Direct Investment Promote Growth? Exploring the Role of Financial Markets on Linkages", Journal of Development Economics, Vol. 91, pp. 242-256, Available at: <http://econweb.umd. edu/ kalemli/assets/publications/foreign2010jde.pdf $>$ [Accessed: May 27, 2019].

Anas, J. et al. (2004) "Business Cycle Analysis with Multivariate Markov Switching Models. Growth and Cycle in the Eurozone 2004", pp. 249-260, Available at: $<$ https://citeseerx.ist.psu.edu/viewdoc/download?doi=10.1.1.198.9647\&rep=re p1\&type $=$ pdf $>$ [Accessed: May 2, 2019].

Andolfatto, D. (2008) Macroeconomic Theory and Policy, 2nd ed.; Simon Fraser University, Available at: <https://mpra.ub.uni-muenchen.de/6403/1/MPRA paper_6403.pdf $>$ [Accessed: on 23 April 23, 2019)].

Angelescu, C., Socol, C. (2005) Politici economice, Bucharest: Economic Publishing.

Angelini, E., Camba-Mendez, G., Giannone, D., Reichlin, L., Rünstler, G. (2011). "Short-Term Forecasts of Euro Area GDP Growth", Econometrics Journal, Vol. 4, pp. C25-C44, Available at: <https://www.ecb.europa.eu/pub/pdf/scpwps/ ecbwp949.pdf?c0247f2d41bf052a82b2a910265528a0> [Accessed: June 14, 2019].

Angelini, E., et al. (2011) "Short-Term Forecasts of Euro Area GDP Growth", The Econometrics Journal, Vol. 14, No. 1, pp. C25-C44, Available at: <https:// www.jstor.org/stable/23127215?seq=1> [Accessed: April 28, 2019]. 
Ardielli, E. (2016) "Implementation of Good Governance Concept in the European Union Member Countries", Proceedings of the $3^{\text {rd }}$ International Conference of European Integration, Ostrava, Czech Republic, May 19-20, Available at: $<$ https://www.researchgate.net/profile/Magdalena_Zajaczkowska/ publication/308360506_Threats_and_Challenges_to_EU_Energy_Security/ links/57e1f13508ae9e 25307d4da8/Threats-and-Challenges-to-EU-EnergySecurity.pdf\#page $=29>$ [Accessed: June 11, 2019].

Barro, R.J. (1991) "Economic growth in a cross-section of countries", Quarterly Journal of Economics, Vol. 106, No. 2, pp. 407-443, Available at: <http:// piketty.pse.ens.fr/files/Barro91.pdf> [Accessed: November 25, 2020].

Barro, R.J., Sala-i-Martin, X. (1992) "Convergence”, Journal of Political Economy. Vol. 100, No. 2, pp. 223-251, Available at: <https://dash.harvard.edu/bitstream/ handle/1/3451299/Barro_Convergence.pdf> [Accessed: November 25, 2020].

Baumol, W.J. (1986) "Productivity Growth, Convergence, and Welfare: What the Long-Run Data Show", American Economic Review, Vol. 76, No. 5, pp. 10721085, Available at: <http://piketty.pse.ens.fr/files/Baumol1986.pdf $>$ [Accessed: November 25, 2020].

Beggs, J. (2019) Understanding the Impact of Growth Rate Differences, May 23, Available at: <https://www.thoughtco.com/economic-growth-and-the-ruleof-70-1147521> [Accessed: June 8, 2019].

Berg, A., Ostry, D.J., Zettelmeyer, J. (2012) "What Makes Growth Sustained?", Journal of Development Economics, Vol. 98, No. 2, pp. 149-166, Available at: $<$ https://ideas.repec.org/a/eee/deveco/v98y2012i2p149-166.html> [Accessed: May 27, 2019].

Boia, L. (2012) Why is Romania different? Bucharest: Humanitas Publisher

Cheshire, P., Magrini, S. (2000) "Endogenous Processes in European Regional Growth: Convergence and Policy", Growth Change - Proceeding of 2nd Workshop on Endogenous Growth: Models and Regional Policy, Amsterdam, Netherlands, Feb 1999; WILEY: Hoboken, USA, Vol. 31, No. 4, pp. 455-479, https://doi.org/10.1111/0017-4815.00140.

D'Ergole, M.M., Salvini, A. (2003) “Towards sustainable development: the role of social protection", OECD Social, Employment and Migration Working Papers, No. 12, Available at: <http://www.oecd.org/social/soc/16362056.pdf> [Accessed: May 21, 2019].

Dabrowski, M. (1995) "Western Aid Conditionality and the Post-Communist Transition”, CASE Network Studies and Analyses, Vol. 37, http://dx.doi. org/10.2139/ssrn.1479560.

Davis, S.L. (2010) "Institutional Flexibility and Economic Growth", Journal of Comparative Economics, Vol. 38, No 3, pp. 306-320, Available at: <https:// ideas.repec.org/a/eee/jcecon/v38y2010i3p306-320.html> [Accessed: May 26, 2019]. 
Eicher, S. T., Schreiber, T. (2010) "Structural Policies and Growth: Time Series Evidence from a Natural Experiment", Journal of Development Economics, Vol. 91, No. 1, pp. 169-179, Available at: <https://ideas.repec.org/a/eee/deveco/ v91y2010i1p169-179.html> [Accessed: May 26, 2019].

Estrin, S., Mickiewicz, T. (2010) "Entrepreneurship in Transition Economies: The Role of Institutions and Generational Change", IZA Discussion Paper, No. 4805, pp. 1-43, Available at: <http://ftp.iza.org/dp4805.pdf> [Accessed: November 3, 2020].

European Commission (2018) European Economic Forecast, Institutional Paper 089, Available at: <https://ec.europa.eu/info/sites/info/files/economy-finance/ ip089_en_0.pdf> [Accessed: on 18 May 18, 2019].

Fingleton, B. (1997) "Specification and Testing of Markov Chain Models: An Application to Convergence in the European Union", Oxford Bulletin of Economics and Statistics, Vol. 59, No. 3, pp. 385-403, Available at: <https:// ideas.repec.org/a/bla/obuest/v59y1997i3p385-403.html> [Accessed: May 3, 2019].

Fontaine, P. (2010) Europe in 12 Lessons, Luxemburg: European Commission, Available at: $<$ https://europa.rs/images/publikacije/26-EU_In_12_Lessons.pdf $>$ [Accessed: June 11, 2019].

Friedman, T. (2008) Hot, Flat, and Crowded: Why We Need a Green Revolution and How It Can Renew America; New York: Farrar, Straus and Giroux.

Gherasim, O., (2008) "Fuzzy Models in Decision-Making", Proceedings of International Conference on Computational Intelligence for Modelling, Control and Automation, Vienna, Austria, Dec 10-12, pp. 958-962.

Haller, A.P. (2011) "Exports in the Knowledge-Based Economy. Romania's Case", Management of technological changes, Book 1, Proceedings of the $7^{\text {th }}$ International Conference Management and Technological Changes, Alexandroupoli, Greece, September 01-03, 2011, Democritus Univ Thrace: Komotini, Greece, pp. 513-516, Available at: <https://www.researchgate.net/ publication/309577886_EXPORTS_IN_THE_KNOWLEDGE-BASED_ ECONOMY_ROMANIA'S_CASE> [Accessed: June 13, 2019].

Haller, A.P. (2020) "From Classical and Neoclassical Economic Growth to Degrowth in Europe. Challenges for Public Administration", Administraţie şi Management Public, Vol. 34, pp. 150-170, https://doi.org/10.24818/ amp/2020.34-9.

Havrylyshyn, O., Meng, X., Tupy, M. (2016) "25 years of reforms in ex-Communist countries: fast and extensive reforms led to higher growth and more political freedom", Cato Institute Policy Analysis, Policy Analysis No. 795, Available at: $<$ https://www.cato.org/publications/policy-analysis/25-years-reforms-excommunist-countries-fast-extensive-reforms-led $>$ [Accessed: November 3, 2020]. 
Herman, D. (2015) Economics for a Full World. Great Transition Initiative. Toward Transformative Vision and Praxis, Available at: <https://greattransition.org/ images/Daly-Economics-for-a-Full-World.pdf> [Accessed: March 18, 2019].

Iancu, A. (2009) Convergenta reala, Bucharest: NIER-CIDE, Available at: $<$ http:// www.studii-economice.ro/2009/seince090701.pdf> [Accessed: March 11, 2019].

IMF (2017) World Economic Outlook: Seeking Sustainable Growth, Short-Term Recovery, Long-Term Challenges, Available at: <https:/www.imf.org/en/ Publications/WEO/Issues/2017/09/19/world-economic-outlook-october-2017> [Accessed: April 28, 2019].

INS (2019) Available at: <https://insse.ro/cms/> [Accessed: April 28, 2019].

Kireyev, A., Chen, J. (2017) Inclusive Growth Framework, IMF WP/17/127, Available at: <https://www.imf.org/en/Publications/WP/Issues/2017/05/30/ Inclusive-Growth-Framework-44951> [Accessed: on 18 May 18, 2019].

Kooros, S., Badeaux, L. (2007) "Economic Development Planning Models: A Comparative Assessment", International Research Journal of Finance and Economics, Vol. 77, No. 7, pp. 120-140, Available at: <https://www. rrojasdatabank.info/ecdevplanningmodels07.pdf $>$ [Accessed: April 28, 2019].

Korten, D. (2010) Agenda for a New Economy: From Phantom Wealth to Real Wealth, Second Edition, Oakland: Berrett-Koehler Publishers.

Le Gallo, J. (2004) "Space-time analysis of GDP disparities among European regions: a Markov chains approach", International Regional Science Review, Vol. 27, No. 2, pp 138-163, Available at: <https://journals.sagepub.com/doi/ abs/10.1177/0160017603262402> [Accessed: June 11, 2019].

Lipták, K. (2012) “The Application of Markov Chain Model to the Description of Hungarian Market Processes", Zarzadzanie Publiczne, Vol. 4, No. 16, pp. 133149, Available at: <http://www.ejournals.eu/sj/index.php/ZP/article/view/1524> [Accessed: June 14, 2019].

London-Lane, J., Robertson, P. (2009) "Long Run Growth in the OECD: A Test of the Parallel Growth Paths Hypothesis", Explorations in Economic History, Vol. 46, No. 3, pp. 346-355, Available at: <https://doi.org/10.1016/j.eeh.2009.04.003> [Accessed: May 10, 2019].

McNabb, K., Le May-Boucher, P. (2014) “Tax Structures, Economic Growth and Development", ICTD-International Centre for Tax and Development, Working Paper 22, Available at: <https://papers.ssrn.com/sol3/papers.cfm?abstract_ id $=2496470>$ [Accessed: 5 June 5, 2019].

Monfort, P. (2008) "Convergence of EU Regions Measures and Evaluation", European Union Regional Policy, No. 1, Available at: <https://ec.europa.eu/ regional_policy/sources/docgener/work/200801_convergence.pdf> [Accessed: June 14, 2019]. 
Moosavi, V., Isacchini, G. (2017) "A Markovian model of evolving world inputoutput network.", PLOS ONE, Vol. 12, No. 10, https://doi.org/10.1371/journal. pone. 0186746 .

Nastase, A., et al (2019) "Statistical prediction using to forecast the theory of Markov chains", Journal of Science and Arts, Vol. 2, No. 47, pp. 415-424, Available at: <https://search.proquest.com/openview/aad6d9bfef4ac7544d02d1 0553608d7f/1?pq-origsite $=$ gscholar\&cbl=105793 > [Accessed: May 3, 2019].

Nicolae-Bălan, M., (2009) “The Markoviene Models Use to Study the Evolution of Some Macroeconomic Indicators", Purica I (coord.) "Nonlinear Approaches to Economic Processes", Bucharest: Editura Expert.

OECD (2020) Available at: <http://www.oecd.org/economy> [Accessed: December $29,2020]$.

Persson, T., Tabellini, G. (2013) "Is Inequality Harmful for Growth?", American Economic Review, Vol. 84, No. 3, pp. 600-621, Available at: <https:// econpapers.repec.org/article/aeaaecrev/v_3a84_3ay_3a1994_3ai_3a3_3ap_3a 600-621.htm> [Accessed: May 28, 2019].

Ponzio, S., Di Gennaro, L. (2004) "Growth and Markov chains: An application to Italian provinces.", Research in Economics: Aims and Methodologies, Second $\mathrm{PhD}$ Conference in Economics, Pavia, Italy, Sept 23-25, pp. 23-25, Available at: < https://www.semanticscholar.org/paper/GROWTH-AND-MARKOVCHAINS-\%3A-AN-APPLICATION-TO-Ponzio/0b41d6c8f63feb341d9200103 8a396e3c95d0ca0> [Accessed: May 3, 2019].

Quah, D. (1992) "Empirical Cross-Section Dynamics in Economic Growth", European Economic Review, Vol. 37, No. 2-3, pp. 426-434, https://doi. org/10.1016/0014-2921(93)90031-5

Quah, D. (1996) "Regional Convergence Clusters across Europe", European Economic Review, Proceeding of 10th Annual Congress of the European Economic Assoc, Prague, Czech Republic, Vol. 40, No. 3-5, pp. 951-958, https://doi.org/10.1016/0014-2921(95)00105-0.

Rey, J.S. (2010) "Spatial Empirics for Economic Growth and Convergence", Geographical Analysis, Vol. 33, No. 3, pp. 195-214, https://doi.org/10.1111/ j.1538-4632.2001.tb00444.x.

Rodrik, D. (2007) "Industrial development: Some stylized facts and policy directions", Industrial Development for the 21st Century: Sustainable Development Perspectives, New York: United Nations, pp. 7-28, Available at: $<$ https://sustainabledevelopment.un.org/content/documents/full_report.pdf $>$ [Accessed: May 28, 2019].

Rovelli, R., Zaiceva, A. (2013) "Dissupport for economic and political reforms increase during the post-communist transition, and if so, why?", Economics of Transition, Vol. 21, No. 2, pp. 193-240, https://doi.org/10.1111/ecot.12009. 
Rünstler, G., Sédillot, F. (2003) "Short-Term Estimates of Euro Area Real GDP by Means of Monthly Data.", ECB Working Paper, No. 276, Available at: <https:// www.ecb.europa.eu/pub/pdf/scpwps/ecbwp276.pdf?ef693dab796b365f5625a07 d2dfcc152> [Accessed: May 3, 2019].

Sbardella, A., Pugliese, E., Pietronero, L. (2017) "Economic development and wage inequality: A complex system analysis", PLOS ONE, Vol. 12, No. 9, https://doi. org/10.1371/journal.pone.0182774.

Sekreter, A. (2015) "What is the Truth? Financial Development Causes Economic Growth or Economic Growth Causes Financial Development", The Empirical Economics Letters, Vol. 14, No. 12, pp. 1207-1214, Available at: <https://www. econbiz.de/> [Accessed: January 11, 2019].

Sledge, I.J., Emigh, M.S., Príncipe, J.C. (2018) "Guided policy exploration for Markov decision processes using an uncertainty-based value-of-information criterion", IEEE Transactions on Neural Networks and Learning Systems, Vol. 29, No. 6, pp. 2080-2098, doi:10.1109/TNNLS.2018.2812709.

Sledge, I.J., Príncipe, J.C. (2019) "Reduction of Markov Chains Using a Value-ofInformation-Based Approach", Entropy, Vol. 21, No. 4, https://doi.org/10.3390/ e21040349.

Smętkowski, M., Wójcik, P. (2010) "Regional Development in Central and Eastern Europe", Regional and Local Studies, Special Issue, pp. 77-106, Available at: $<\mathrm{http}$ ://www.euroreg.uw.edu.pl/dane/web_euroreg_publications files/422/2010_5_smetkowski_wojcik.pdf> [Accessed: May 19, 2019].

Soloviev, V., Saptsin, V., Chabanenko, D. (2011) "Markov Chains Applications to the Financial-Economic Time Series Prediction.", Computer Modelling and New Technologies, Vol. 15, No. 3, pp. 16-20, Available at: <http://elibrary.kdpu. edu.ua/jspui/bitstream/0564/1189/1/15_3-2_soloviev.pdf> [Accessed: June 14, 2019].

Solow, R.M. (1956) "A contribution to the theory of economic growth", Quarterly Journal of Economics, Vol. 70, pp. 65-94, Available at: <http://piketty.pse.ens. fr/files/Solow1956.pdf> [Accessed: November 25, 2020].

Spicer, A., McDermott, G., Kogut, B. (2000) "Entrepreneurship and Privatization in Central Europe: The Tenuous Balance between Destruction and Creation", The Academy of Management Review, Vol. 25, No. 3, pp. 630-649, Available at: $<$ https://www.jstor.org/stable/259315?seq=1> doi: 10.2307/259315. [Accessed: November 3, 2020].

Stiglitz, E.J. et al. (2014) "A Call for Change. From the Crisis to a New Egalitarian Ideal for Europe", Progressive Economy, No. 3, Available at: <https://www. socialistsanddemocrats.eu/sites/default/files/PROGRESSIVE\%20 ECONOMY\%20-\%20A\%20Call\%20for\%20Changes_EN_2.pdf> [Accessed: January 12, 2019]. 
Sýkora, L., Bouzarovski, S. (2011) "Multiple transformations: Conceptualising the Post-Communist Urban Transition", Urban Studies, Vol. 49, No. 1, pp. 43--60, https://doi.org/10.1177/0042098010397402.

UNDP (2017) UNDP's Strategy for Inclusive and Sustainable Growth, New York: UNDP. Available at: <https://www.undp.org/content/dam/undp/library/Poverty\% 20Reduction/UNDPs\%20Inclusive\%20and\%20Sustainable\%20Growth-final. pdf> [Accessed: April 20, 2019].

World Bank (2017) Global Outlook. A Fragile Recovery, Available at: <https:// openknowledge.worldbank.org/bitstream/handle/10986/26800/9781464810244. pdf $>$ [Accessed: June 15, 2019].

Zalewska, A., Mickiewicz, T.M. (2006) "Deindustrialisation: Lessons from the Structural Outcomes of Post-Communist Transition", William Davidson Institute Working Paper 463, http://dx.doi.org/10.2139/ssrn.311410.

Zhalezka, B., Navitskaya, K. (2015) "Multi-Criteria Fuzzy Analysis of Regional Development", Econtechmod. An International Quarterly Journal, Vol. 4, No. 3, pp. 39-46, Available at: <http://journals.pan.pl/dlibra/publication/99247/ edition/85552/content> [Accessed: June 14, 2019]. 


\title{
Srednjoročna prognoza europskog ekonomskog održivog rasta pomoću Markovljevih lanaca
}

\author{
Alina-Petronela Haller ${ }^{1}$, Ovidiu Gherasim ${ }^{2}$, Mariana Bălan ${ }^{3}$, Carmen Uzlău 4
}

\begin{abstract}
Sažetak
Gospodarski rast je s teorijskog $i$ empirijskog stajališta često analizirani aspekt pod utjecajem faktora utjecaja, dok je pitanje gospodarskog rasta proučavano različitim metodama is različitim rezultatima. U slučaju EU28, u svezi problema ekonomske konvergencije mora se uzeti u obzir činjenica da su države članice heterogene u pogledu razvoja $i$ brzine rasta. U ovom radu, uz primjenu Markovljevih lanaca za gospodarstva država članica EU28 dana je prognoza razvoja BDP-a po stanovniku, počevši od poznatog vremenskog horizonta za period 1997. - 2016., s ciljem približavanja horizontu predviđanja za period 2017. - 2028. Dobiveni rezultati pokazuju da će proces konvergencije biti spor u slučaju nekih država članica, napose u zemljama Srednje i Istočne Europe. Buduća ekonomska dinamika intenzivirat će razlike u rastu, ponajprije u slučaju europske periferije, koja će pretrpjeti manje izmjene; države s najdubljim jazom ostat će Bugarska i Rumunjska.
\end{abstract}

Ključne riječi: ekonomski rast, Markovljevi lanci, srednjoročna prognoza, konvergencija, EU28

JEL klasifikacija: F43, N10, O11, O47, O52, R11

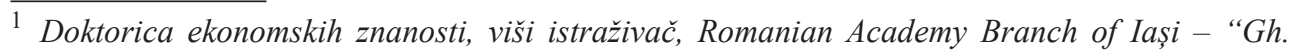
Zane" Institute for Economic and Social Research, Codrescu Str, No. 2, 700481, Iasi, Rumunjska. Znanstveni interes: gospodarski rast, gospodarski razvoj, nejednakosti, međunarodni turizam, međunarodna ekonomija, makroekonomija. E-mail: alina_haller@ yahoo.com. Osobna web stranica: https://sites.google.com/view/alinahaller/home. ORCID ID: https://orcid.org/0000-0002-2069-9889.

2 Doktor ekonomskih znanosti, viši istraživač, Romanian Academy Branch of Iași - "Gh. Zane” Institute for Economic and Social Research, Codrescu Str, No. 2, 700481, Iasi, Rumunjska. Znanstveni interes: neizraziti sustavi, primijenjena matematika, informacijski sustavi. E-mail: ogacadr@yahoo.com.

${ }^{3}$ Redovita profesorica, viši istraživač, Institute for Economic Forecasting - NIER, Romanian Academy, Casa Academiei, Calea 13 Septembrie No.13, 050711, Bukurešt, Rumunjska. Znanstveni interes: ekonomsko predviđanje, ekonometrija i modeliranje, ekonomska statistika, makroekonomija, mobilnost stanovništva i radne snage, tržište rada, demoekonomija, razvijanje javnih politika za zapošljavanje mladih, tržište obrazovanja, tehnološki napredak nasuprot obrazovanju i osposobljavanju za ljudske resurse.E-mail: dr.mariana.balan@gmail. com.

${ }^{4}$ Doktorica ekonomskih znanosti, viši istraživač, Institute for Economic Forecasting - NIER, Romanian Academy, Casa Academiei, Calea 13 Septembrie No.13, 050711, Bukurešt, Rumunjska. Znanstveni interes: tržište obrazovanja, socijalna zaštita, fiskalne politike, makroekonomija, ekonomski razvoj, ekonomska statistika.E-mail: carmen.uzlau1812@gmail. com. 